\title{
THE NATURE OF THE PIGMENTS IN THE CROWNS OF SABELLID AND SERPULID POLYCHAETES
}

\author{
By R. Phillips Dales \\ Bedford College, University of London
}

(Text-figs. I-4)

The crowns of many sabellids and serpulids have brilliant purple, red, orange or other colours forming distinct patterns. Some species have several colour varieties. Specimens of Eudistylia polymorpha, for example, have crowns which are either a deep claret colour or are yellow, but a few have crowns that are virtually colourless. Pomatoceros triqueter crowns are blue, orange, or varying shades of brown and green. The chemical nature of these colours has been hitherto unknown; the present purpose is to call attention to the several kinds of pigment that have been found.

The following sabellids have been studied: Myxicola infundibulum (Renier), Sabella spallanzanii (Viviani), S. pavonina Savigny, Branchiomma vesiculosum (Montagu), Schizobranchia insignis Bush, Eudistylia polymorpha (Johnson), E. vancouveri (Kinberg), Pseudopotamilla occelata Moore, and Chone infundibuliformis Kröyer; and the serpulids: Serpula vermicularis L., Protula intestinum (Savigny) Pomatoceros triqueter (L.), and Galeolaria caespitosa Savigny.

Most of the work has been done at the Plymouth Laboratory, and I am glad of this opportunity to thank the Director and Staff for their help. Some results were also obtained during visits to the Hopkins Marine Station of Stanford University at Pacific Grove, the Friday Harbor Laboratories of the University and the Stazione Zoologica at Naples. I would like to thank Prof. L. R. Blinks of Pacific Grove, Prof. R. L. Fernald and his colleagues at Friday Harbor, and Dr A. Dohrn and the Staff at Naples for their many courtesies. I am also grateful to the Royal Society for their generosity, to Prof. A. Stock of the University of New England, Armidale, for sending me specimens of Galeolaria from New South Wales, and to Dr Bernt Linzen for his analysis of some of the extracts and permitting me to include his results here. I also wish to thank Prof. D. L. Fox of the Scripps Institution for his advice on reagents available in the United States, and Dr J. Green for reading the typescript of this paper. 


\section{METHODS}

Fresh crowns were used, without homogenization, to obtain extracts of the pigments so that these could be identified with the markings in the living crown. Carotenoids were first extracted with acetone, and the crowns then placed in distilled water. In most instances crowns still contained a considerable amount of pigment after such treatment. They were then subjected to aqueous acid $(5 \mathrm{~N}-\mathrm{HCl}), \mathrm{I} \% \mathrm{HCl}$ : methanol, ethylene chlorhydrin (2-chloro-ethanol), and $0.2 \%$ aqueous $\mathrm{NaOH}$. Individual crowns were examined under a microscope at each step to determine which colours were removed.

The carotenoids were taken into light petroleum (b.r. $40-60^{\circ} \mathrm{C}$ was used throughout) by addition of water to the acetone extract, and were saponified with $12 \%$ methanolic KOH. After saponification the pigments were re-extracted with diethyl ether, evaporated to dryness and redissolved in light petroleum in which the mixture was chromatographed on alumina. In England, B.D.H. Brockman alumina was used without activation; in the United States, Alcoa activated alumina XF-2I grade was used without further treatment. The column was developed with acetone-light petroleum mixtures, and the resulting bands eluted, evaporated to dryness and redissolved in light petroleum. On shaking with $90 \%$ methanol those fractions remaining in the epiphase were rechromatographed on magnesium oxide in light petroleum, whilst hypophasic pigments were returned to light petroleum and rechromatographed on icing sugar. In England, Tate and Lyle icing sugar containing $\mathrm{I} \frac{1}{2} \%$ calcium phosphate was used; in the United States $\mathrm{C}$ and $\mathrm{H}$ brand confectionary sugar, after drying overnight. Magnesium oxide columns were developed with acetone-light petroleum, sugar columns with $n$-propanol-light petroleum mixtures.

The absorption spectra of epiphasic carotenoids were examined in $n$-hexane and carbon disulphide; hypophasic carotenoids in ethanol and carbon disulphide. All absorption spectra were determined with a Unicam S.P. 500 spectrophotometer in England, and with a Beckman D.U. in the United States and at Naples.

Opportunity did not always allow an equally thorough analysis of the pigments of every species mentioned; any variations in technique are noted in each case.

\section{OBSERVATIONS}

\section{Myxicola infundibulum}

SABELLIDAE

The crowns commonly have a purple or brownish-purple colour, most of the pigment being concentrated in the free tips of the filaments and towards the base. In some worms the colour extends throughout the crown filaments and into the pinnules, but others have been found with virtually no pigment in the crown.

The quantity of carotenoid in the crown varies considerably, but there is little compared with the amount deposited in the epidermis of the remainder of the body. On alumina the bands shown in Fig. I were obtained. Band 5 passed rapidly down the column with light petroleum and its spectrum agreed with that of $\alpha$-carotene. The spectrum, colour, position on the column and behaviour of band 4 suggested $\beta$-carotene. The orange-red band 3 above was separated from the main band I with a mixture of $20 \%$ acetone-light petroleum, and exhibited a single absorption maximum in $n$-hexane and 


\begin{tabular}{|c|c|c|c|c|c|c|c|c|}
\hline \multirow[b]{2}{*}{$\begin{array}{l}\text { Band } \\
\text { no. }\end{array}$} & \multirow[b]{2}{*}{ Colour } & \multirow[b]{2}{*}{ Elution } & \multicolumn{2}{|c|}{ Phase test with $90 \%$ methanol } & \multicolumn{4}{|c|}{ Absorption maxima } \\
\hline & & & $\begin{array}{c}\text { Before } \\
\text { saponification }\end{array}$ & $\begin{array}{c}\text { After } \\
\text { saponification }\end{array}$ & Ethanol & Hexane & $\mathrm{CS}_{2}$ & Pyridine \\
\hline I & Red & Acetic ether & Epiphasic & $\begin{array}{l}\text { Hypophasic } \\
\text { when alkaline }\end{array}$ & - & - & 507 & 492 \\
\hline 2 & Yellow & $\begin{array}{l}50 \% \text { acetone } \\
\text { light petroleum }\end{array}$ & Hypophasic & Hypophasic & $(422) / 445 / 475$ & $448 / 475$ & $475 / 505$ & - \\
\hline 3 & $\begin{array}{l}\text { Orange- } \\
\text { red }\end{array}$ & $\begin{array}{l}20 \% \text { acetone } \\
\text { light petroleum }\end{array}$ & Epiphasic & $\begin{array}{l}\text { Hypophasic } \\
\text { when alkaline }\end{array}$ & - & $46 \mathrm{I}$ & 496 & - \\
\hline 4 & Orange & Light petroleum & Epiphasic & Epiphasic & - & $(428) / 45 \mathrm{I} / 475$ & $485 / 520$ & - \\
\hline 5 & $\begin{array}{l}\text { Lemon- } \\
\text { yellow }\end{array}$ & Light petroleum & Epiphasic & Epiphasic & - & $425 / 448 / 475$ & $445 / 478 / 508$ & - \\
\hline
\end{tabular}

Fig. I. Carotenoids from the crown of Myxicola infundibulum as they appear on alumina when developed with light petroleum: acetone mixtures. 
carbon disulphide. The only hypophasic component which had a lutein-like absorption spectrum, was eluted with $50 \%$ acetone in light petroleum. The red band at the top of the column which represented the bulk of the total carotenoid could be eluted only with diethyl ether acidified with acetic acid. It showed a spectrum similar to that of astaxanthin and when partitioned with $90 \%$ methanol was hypophasic in the presence of alkali, epiphasic in the presence of acid. The epiphasic nature of the pigment in the original extract suggests that it was esterified.

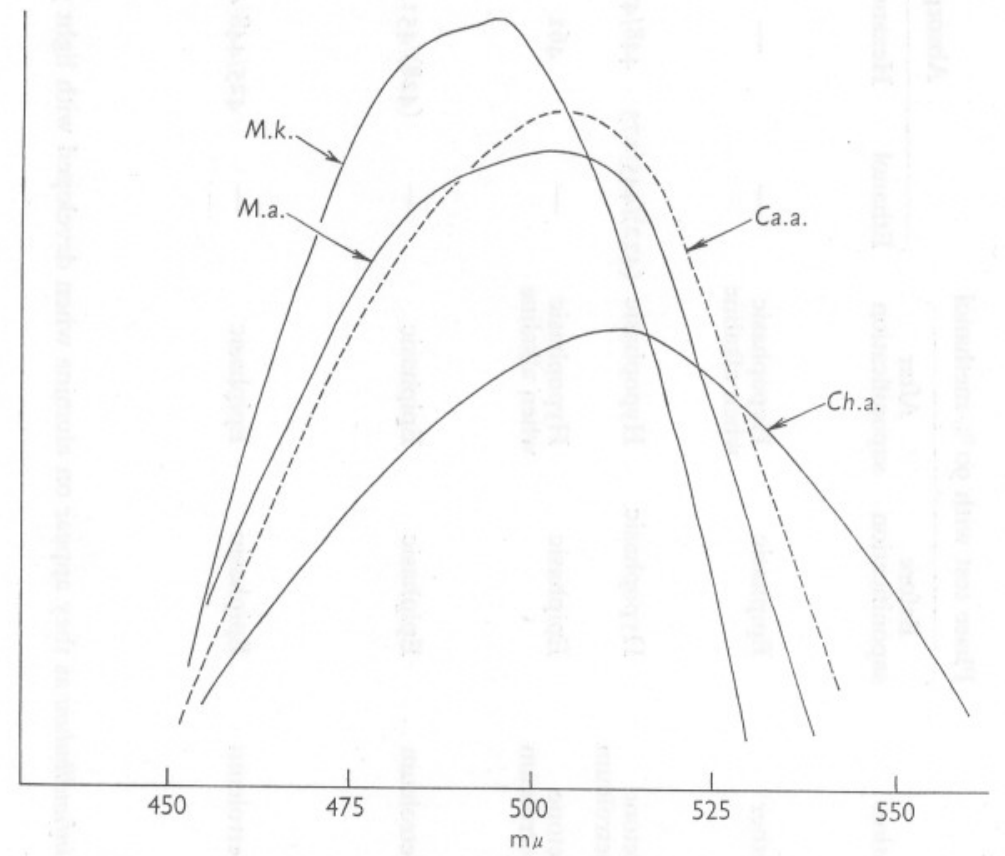

Fig. 2. Absorption spectra of astaxanthin from Myxicola infundibulum (M.a.) and Chone infundibuliformis (Ch.a.) in carbon disulphide, compared with that from Carcinus maenas (Ca.a.) and the absorption spectrum of the suspected intermediate ketocarotenoid from Myxicola (M.k.) dissolved in the same solvent.

In view of the predominating carotenoid being identified as astaxanthin or astaxanthin ester, it is possible that the pigment forming band 3 and showing a single absorption maximum at $496 \mathrm{~m} \mu$ in carbon disulphide is a ketocarotenoid intermediate between $\beta$-carotene and astaxanthin. The pigment showed a behaviour similar to that of astaxanthin when partitioned with $90 \%$ methanol. The absorption spectra of Myxicola astaxanthin and this possible intermediate ketocarotenoid are compared with that of astaxanthin from the shore crab Carcinus maenas in Fig. 2. The absorption maxima of each pigment in Fig. I were obtained from solutions which had been rechromatographed on magnesium oxide or sugar. 
After complete extraction of carotenoid a purple colour remained. A pinkish-yellow solution was obtained with $5 \mathrm{~N}-\mathrm{HCl}$ and more readily with $\mathrm{I} \% \mathrm{HCl}$ : methanol mixture. In $5 \mathrm{~N}-\mathrm{HCl}$ the spectrum showed maxima at 265, 320 and $445 \mathrm{~m} \mu$. Extraction was slow, but almost all the pigment was eventually dissolved by acid solvents. The pigment was reduced by potassium borohydride, and by sodium dithionite in slightly alkaline solution to a pink colour, the original colour returning after some time in air. A brownish-purple pigment which remained, dissolved slowly in $0.2 \%$ sodium hydroxide and in ethylene chlorhydrin and had a featureless absorption spectrum in both solvents.

\section{Sabella spallanzanii}

The colour of the crowns varies in depth of hue but not in pattern. As in Sabella pavonina some individuals have rather orange crowns and others have crowns very distinctly barred with purple marks. In all specimens the pattern is built up by bars of orange, purple and white repeated in that order from the base to the tip of the filament so that spirals of colour are displayed when the crown is fully open.

The amount of carotenoid present varies from one individual to another. The carotenoids in the coelomic cells have been described elsewhere (Dales, I96I) and those in the crown are the same. The result of analysis of acetone extracts was similar to that obtained with Myxicola, except that far more of the suspected intermediate ketocarotenoid, with a maximum absorption at 494-496 $\mathrm{m} \mu$ in carbon disulphide, was obtained. Furthermore, a mixed chromatogram with band 3 of Myxicola failed to separate, while in a mixed chromatogram with $\beta$-carotene prepared from carrots, the Sabella pigment remained above the $\beta$-carotene on the column. Chromatography on magnesium oxide always effected a separation of an $\alpha$-carotene-like pigment (perhaps pseudo- $\alpha$-carotene formed during the previous treatment) as well as $\beta$-carotene; whilst chromatography of the hypophasic pigments on sugar revealed on some occasions two lutein-like compounds.

After extraction of the carotenoid much of the orange colour remained. This readily dissolved in $5 \mathrm{~N}-\mathrm{HCl}$ and more readily in $\mathrm{I} \% \mathrm{HCl}$ : methanol to give a golden yellow solution. In $5 \mathrm{~N}-\mathrm{HCl}$ maxima were shown at 255 and $455 \mathrm{~m} \mu$. As with the acid-soluble pigment from Myxicola, there was no fluorescence and addition of dithionite to a slightly alkaline solution reduced it to a pink colour which slowly changed to yellow in air. The pigment was not taken up by neutral organic solvents. Ascending partition paper chromatography using a collidine/lutidine/water, $I: I: 2$ system, gave a streak of $R_{F} 0.7$ suggesting an ommin.

The purple bands were insoluble in aqueous acid and acid methanol while dissolving slowly in ethylene chlorhydrin to form a dark blue-black solution. After complete extraction of the orange pigment with $8 \% \mathrm{HCl}$, the purple 
pigment could be dissolved in $0.2 \%$ sodium hydroxide to give a pink solution, but the colour faded in a few hours. The pigment acted as an indicator, being blue-black in acid, red in alkaline media, the purple colour in the living filament representing neutrality.

\section{Sabella pavonina}

The filaments have a predominantly orange hue with bars of purple pigment giving a concentric effect when the crown is displayed. Much of the orange colour is due to carotenoid, but there is in addition a yellow watersoluble pigment and an orange acid-soluble pigment.

The carotenoid complement is like that of $S$. spallanzanii in having a large amount of the suspected intermediate ketocarotenoid (maximum $496 \mathrm{~m} \mu$ in carbon disulphide) a smaller quantity of astaxanthin (probably esterified), a single lutein-like xanthophyll, $\beta$-carotene and the $\alpha$-carotene-like pigment.

After acetone extraction, a yellow pigment may be dissolved out with distilled water with a single absorption maximum at $435 \mathrm{~m} \mu$. It was without fluorescence, nor was any fluorescence observed on addition of acid. It was turned pink by addition of dithionite. $5 \mathrm{~N}-\mathrm{HCl}$ extracted a golden yellow solution showing maxima at 260 and $455 \mathrm{~m} \mu$, reducible to a pink colour with dithionite. The brownish-purple marks did not dissolve in acid, but were soluble in ethylene chlorhydrin and in $0.2 \%$ sodium hydroxide to give a pink solution. More concentrated alkali turned the purple pigment brown.

\section{Branchiomma vesiculosum}

The crowns vary in colour from a greenish grey to purple with white marks. The subterminal eyes are screened with purple pigment. Some carotenoid is present and on analysis proved to be largely astaxanthin (maximum $505 \mathrm{~m} \mu$ in carbon disulphide) together with $\beta$-carotene. No other carotenoids were identified from the few individuals that were examined. No water soluble pigments were detected. $5 \mathrm{~N}-\mathrm{HCl}$ extracted a yellow pigment which was more readily dissolved by $\mathrm{I} \% \mathrm{HCl}$ : methanol in which maxima were shown at 260 and $460 \mathrm{~m} \mu$, the solution, after neutralization, being reducible to a pink colour with dithionite. The purple pigment which remained was resistant to acid solution but dissolved instantly in alkalis to give a pink solution.

\section{Schizobranchia insignis}

Worms belonging to this species vary greatly in crown colour: some have orange crowns, in others the crowns are a deep claret in colour, still others have grey crowns with white marks. All kinds are found together, and as each kind includes worms of every size it seems that these are individual differences. It is convenient to consider three types: worms in which the crown is (I) claret, (2) orange, or (3) grey. The grey crowns are particularly variable, for some are almost colourless save for a few greenish-grey bands 
and white marks, others almost completely dark grey in colour. There are intermediate forms between all three types. Of forty-one randomly collected worms, thirteen had purely claret coloured crowns, three pure orange, the remainder were intermediate with a variable amount of grey pigment.

Acetone extracted the majority of the pigment of orange crowns, and some carotenoid was present in all three types. Astaxanthin showing an absorption maximum at $502-508 \mathrm{~m} \mu$ in carbon disulphide was the predominant pigment, but the suspected intermediate ketocarotenoid showing maxima at $46 \mathrm{I} \mathrm{m} \mu$ in hexane and $494 \mathrm{~m} \mu$ in carbon disulphide, together with $\beta$ carotene, an $\alpha$-carotene-like pigment and a single lutein-like xanthophyll were also present.

Some orange pigment remained after acetone extraction even in orange crowns, $5 \mathrm{~N}-\mathrm{HCl}$ extracts showed maxima at 265 and $465 \mathrm{~m} \mu, \mathrm{I} \% \mathrm{HCl}$ : methanol at 265, 390 and $455 \mathrm{~m} \mu$ and showing the redox behaviour similar to the extracts obtained from other sabellids. The pigments remaining in the claret crowns proved more difficult to dissolve, and the crowns turned a brownish-black when immersed in $5 \mathrm{~N}-\mathrm{HCl}$, strongly resembling the darkest of the naturally occurring grey crowns. I $\% \mathrm{HCl}$ : methanol produced a deep claret-coloured solution showing maxima at 260,390 and $520 \mathrm{~m} \mu .0 .2 \%$ sodium hydroxide dissolved all the pigment and instantly gave a deep pink solution. This could be turned yellow by addition of acid, and the colour was reversible providing not too much acid had been added. A deep golden extract was obtained from the grey crowns with $5 \mathrm{~N}-\mathrm{HCl}$, and more readily with $\mathrm{I} \% \mathrm{HCl}$ : methanol, in which maxima were shown at 290,395 and $450 \mathrm{~m} \mu$. This solution was reduced to a pink colour with dithionite when made slightly alkaline.

\section{Eudistylia polymorpha}

This Californian species owes its name to three distinct colour varieties. Unlike Schizobranchia insignis there seem to be no intermediates. Individuals have crowns that are either (I) claret, (2) yellow, or (3) 'colourless'. The first two varieties are perhaps equally numerous, though of eleven randomly collected worms from one locality, three had claret-coloured crowns, seven were orange, and only one was 'colourless'.

Some carotenoid was found even in the 'colourless' variety. In acetone extracts pooled from crowns of all three types, astaxanthin (showing maximum absorption at $498-502 \mathrm{~m} \mu$ in carbon disulphide, $485 \mathrm{~m} \mu$ in pyridine), the suspected ketocarotenoid, $\beta$-carotene, the $\alpha$-carotene-like pigment and a single lutein-like xanthophyll were identified. The rather low absorption maximum of the astaxanthin may have been due to imperfect separation from the lutein-like pigment.

In the claret crowns the pigment granules, which are rather less than $\mathrm{I} \mu$ across, may be seen to mingle with small groups of similar granules with 
an orange colour, suggesting that the two colours are different phases of the same pigment. Boiling the crowns in water changed the colour to a purplish brown, but did not effect solution. Alkali dissolved the granules to form an amber solution, but the pigment was more readily dissolved in $5 \mathrm{~N}-\mathrm{HCl}$ or I $\% \mathrm{HCl}$ : methanol. From this solution the pigment could be precipitated by neutralization and dilution, and the precipitate when redissolved in $5 \mathrm{~N}-\mathrm{HCl}$ showed maxima at 267 and $515 \mathrm{~m} \mu$. All the pigment remaining in claret crowns after acetone extraction could be dissolved in acid or acid methanol. It showed the redox properties shown by the extracts similarly obtained from other sabellids.

A golden yellow extract was obtained by immersing the yellow crowns in acid or acid methanol, and when reduced with dithionite could be precipitated and redissolved in $5 \mathrm{~N}-\mathrm{HCl}$ when maxima were shown at 270 and $445 \mathrm{~m} \mu$. The crude extract had additional maxima at 320 and $392 \mathrm{~m} \mu$, as in the case of the claret crowns.

A weak yellow solution, which showed redox behaviour, could be extracted with acid even from 'colourless' crowns.

\section{Eudistylia vancouveri}

Unlike $E$. polymorpha, individuals of $E$. vancouveri differ little in their crown colour. Each filament has alternating bars of a dark green and a deep claret colour. Both pigments are present in granules of about $\mathrm{I} \mu$ across.

The main carotenoid present again proved to be astaxanthin (maximum 498-506 $\mathrm{m} \mu$ in carbon disulphide), accompanied by a single lutein-like xanthophyll, $\beta$-carotene and the $\alpha$-carotene-like pigment.

The green pigment disappeared in animals preserved in alcohol after a short time, but first changed to a brown colour. It readily dissolved in $\mathrm{I} \%$ aqueous $\mathrm{HCl}$ and could partly be separated from the claret pigment in this way, since this proved much less soluble in this solvent. Careful cutting out of the green parts of the crown showed that this colour in $I \%$ aqueous $\mathrm{HCl}$ showed absorption maxima at 265,325 and $675 \mathrm{~m} \mu$ (Fig. 3). Treatment with alkali turned the solution yellow; it had no fluorescence.

The claret pigment did not readily dissolve in $5 \mathrm{~N}-\mathrm{HCl}$, but dissolved instantly in $\mathrm{I} \% \mathrm{HCl}$ : methanol to give a pink solution with maxima at 390 and $505 \mathrm{~m} \mu$. A $5 \mathrm{~N}-\mathrm{HCl}$ extract was yellow and without well-defined maxima, the filaments turning brown when soaked in this strength of acid. After such treatment a pink solution was instantly obtained with methanol. On neutralization a red flock precipitated, and this when dissolved in $5 \mathrm{~N}-\mathrm{HCl}$ showed maxima at 262 and $505 \mathrm{~m} \mu$. 


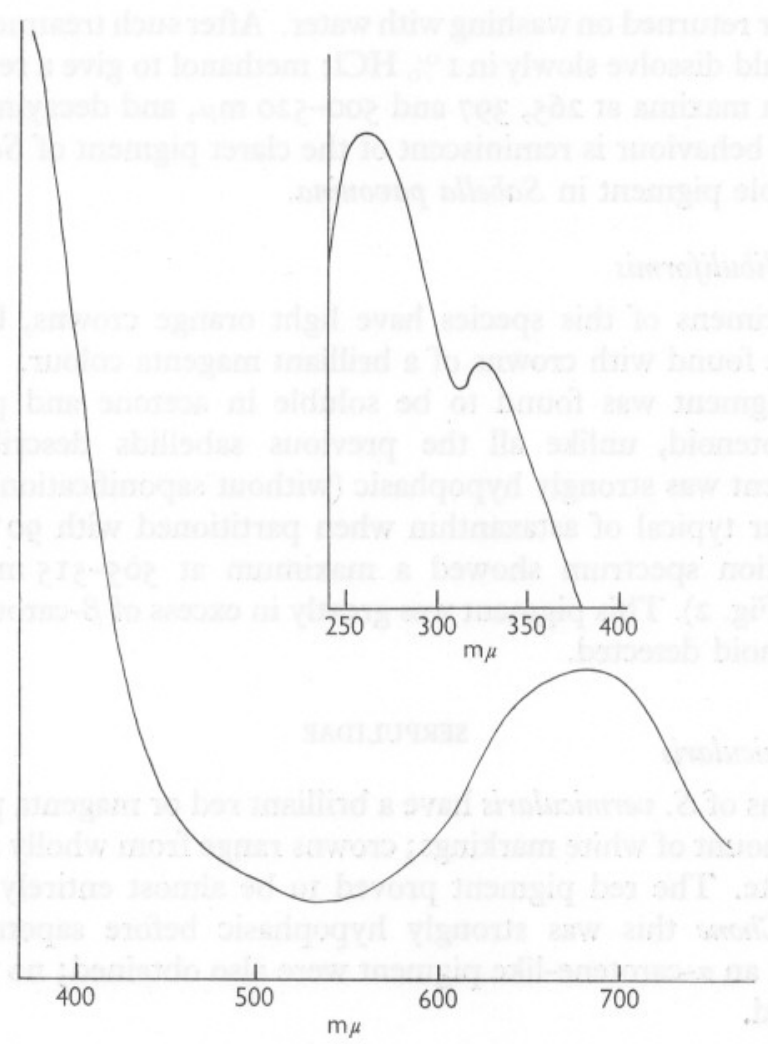

Fig. 3. Absorption spectrum of the green pigment from Eudistylia vancouveri in I $\%$ aq. $\mathrm{HCl}$.

\section{Pseudopotamilla occelata}

The colour of the crown in this species, like that of Schizobranchia insignis is variable. Some worms have almost colourless crowns; some have purple bars alternating with orange marks forming concentric rings of colour when the crown is opened; others have orange crowns with touches of purple pigment. When present in large quantities this purple pigment may give the crown an almost black appearance.

Acetone extracts some carotenoid, though little was found in the worms examined. The major part showed the characteristics of astaxanthin.

The orange pigment readily dissolved in $\mathrm{I} \%$ aqueous $\mathrm{HCl}$ to give a yellow solution; in slightly alkaline solution, it was reduced by dithionite to a pink colour. A $5 \mathrm{~N}-\mathrm{HCl}$ extract showed maxima at 262 and $475 \mathrm{~m} \mu$. The purple pigment did not dissolve in aqueous acid, nor in $\mathrm{I} \% \mathrm{HCl}$ : methanol, but dissolved in $0.2 \%$ sodium hydroxide to give a pink solution. The purple pigment was turned brown in the filaments by $5 \mathrm{~N}-\mathrm{HCl}$ treatment, but the 
purple colour returned on washing with water. After such treatment the purple pigment would dissolve slowly in $\mathrm{I} \% \mathrm{HCl}$ : methanol to give a reddish-purple solution with maxima at 265,397 and 500-520 $\mathrm{m} \mu$, and decaying to a yellow colour. This behaviour is reminiscent of the claret pigment of Schizobranchia and the purple pigment in Sabella pavonina.

\section{Chone infundibuliformis}

Most specimens of this species have light orange crowns, but some individuals are found with crowns of a brilliant magenta colour.

All the pigment was found to be soluble in acetone and proved to be entirely carotenoid, unlike all the previous sabellids described. Nearly all the pigment was strongly hypophasic (without saponification) and showed the behaviour typical of astaxanthin when partitioned with $90 \%$ methanol. The absorption spectrum showed a maximum at $505-515 \mathrm{~m} \mu$ in carbon disulphide (Fig. 2). This pigment was greatly in excess of $\beta$-carotene, the only other carotenoid detected.

\section{Serpula vermicularis SERPULIDAE}

The crowns of $S$. vermicularis have a brilliant red or magenta pigment with a variable amount of white markings; crowns range from wholly red to almost entirely white. The red pigment proved to be almost entirely astaxanthin, and as in Chone this was strongly hypophasic before saponification. $\beta-$ carotene and an $\alpha$-carotene-like pigment were also obtained; no xanthophylls were detected.

\section{Protula intestinum}

The brilliant red colour of the crowns of this serpulid is also due mainly to astaxanthin (maximum $504 \mathrm{~m} \mu$ in carbon disulphide), together with the suspected intermediate ketocarotenoid (maximum $496 \mathrm{~m} \mu$ in carbon disulphide), $\beta$-carotene and a small $\alpha$-carotene-like fraction; no xanthophylls were detected.

\section{Pomatoceros triqueter}

The colours of the crown of Pomatoceros were described by Føyn \& Gjøen (I954) as containing four pigments: blue, red (perhaps better described as pink), yellow, and white, which in varying combination accounted for the three main colour varieties: blue, brown, and orange.

The yellow pigment is present in variable quantity. It seems diffuse and was completely extracted with acetone and proved to be carotenoid. Analysis showed the extract to contain astaxanthin, $\beta$-carotene and a xanthophyll, but unlike the other serpulids examined and unlike all the sabellids, $\beta$-carotene was the predominant carotenoid, and there was relatively little astaxanthin. 
Repeated acetone extraction left both pink and blue pigments untouched. All the pink pigment was then extracted with distilled water in which it formed a pink solution with a faint purple dichroism. The solution had no fluorescence, and in water showed very sharp absorption maxima at 500 and $535 \mathrm{~m} \mu$, but no discernible maxima in the violet or ultra-violet. The pink pigment was insoluble, not only in acetone, but also in methanol, chloroform and

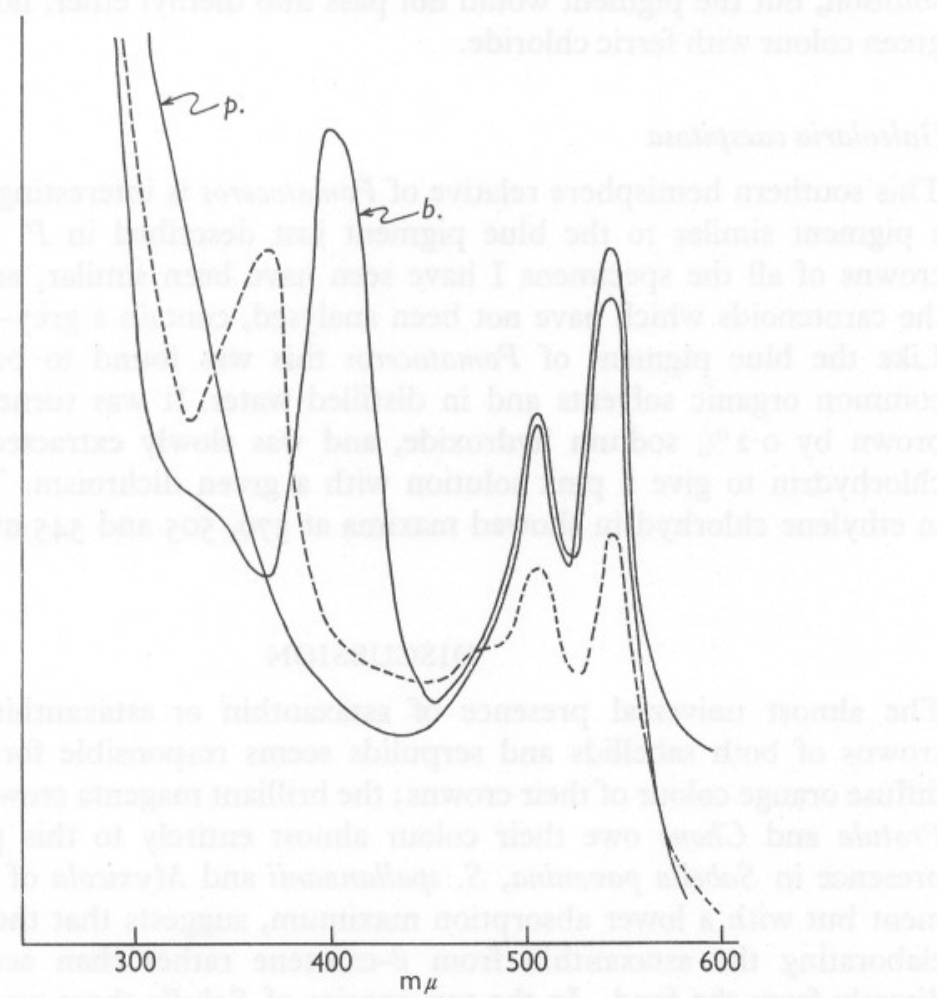

Fig. 4. Absorption spectra of the pink ( $p$.$) and blue (b)$ pigments from Pomatoceros triqueter and the grey-blue pigment from Galeolaria caespitosa (broken line), dissolved in 2-chloroethanol.

diethyl ether. Addition of dithionite turned the aqueous solution a greenishyellow and finally bleached it. The addition of $5 \mathrm{~N}-\mathrm{HCl}$ or acetic acid to the aqueous solution turned the colour to purple, but this was soon destroyed. Hydrogen peroxide also bleached the pigment after a few hours. Evaporation to dryness on a water bath caused some of the pigment to turn blue. Dissolved in ethylene chlorhydrin, maxima were shown at 505 and $545 \mathrm{~m} \mu$ (Fig. 4).

The blue pigment is quite stable, as it may be seen in specimens preserved in alcohol for at least a year, but unlike the pink pigment it does not dissolve in water. It is similar in being insoluble in acetone, diethyl ether, chloroform 
and methanol, and while it was turned pink by $0.2 \%$ sodium hydroxide, it was not dissolved as readily by alkali as by ethylene chlorhydrin which extracted it as a pink solution with a marked green dichroism. The spectrum in this solvent showed maxima at 405,505 , and $542 \mathrm{~m} \mu$, with a shoulder at $272 \mathrm{~m} \mu$, the two highest peaks being similar to those of the pink pigment in the same solvent. Faintly acid acetone readily extracted the blue pigment as a pink solution, but the pigment would not pass into diethyl ether, nor did it give a green colour with ferric chloride.

\section{Galeolaria caespitosa}

This southern hemisphere relative of Pomatoceros is interesting in possessing a pigment similar to the blue pigment just described in $P$. triqueter. The crowns of all the specimens I have seen have been similar, and apart from the carotenoids which have not been analysed, contain a grey-blue pigment. Like the blue pigment of Pomatoceros this was found to be insoluble in common organic solvents and in distilled water. It was turned a purplishbrown by $0.2 \%$ sodium hydroxide, and was slowly extracted by ethylene chlorhydrin to give a pink solution with a green dichroism. The spectrum in ethylene chlorhydrin showed maxima at 370, 505 and $545 \mathrm{~m} \mu$ (Fig. 4).

\section{DISCUSSION}

The almost universal presence of astaxanthin or astaxanthin ester in the crowns of both sabellids and serpulids seems responsible for much of the diffuse orange colour of their crowns; the brilliant magenta crowns of Serpula, Protula and Chone owe their colour almost entirely to this pigment. The presence in Sabella pavonina, S. spallanzanii and Myxicola of a similar pigment but with a lower absorption maximum, suggests that these worms are elaborating the astaxanthin from $\beta$-carotene rather than accumulating it directly from the food. In the two species of Sabella there was always more of this suspected intermediate ketocarotenoid than astaxanthin or astaxanthin ester itself; in Myxicola, Schizobranchia and Eudistylia polymorpha there is much less; in Chone, Branchiomma, Serpula and Pseudopotamilla apparently none. These facts suggest that sabellids have a varying ability to synthesize astaxanthin from $\beta$-carotene, an ability least developed in Sabella and best developed in Chone and Serpula. The occurrence of such an intermediate ketocarotenoid is reminiscent of de Nicola's (1954) work on Ophidiaster, though cryptoxanthin, which she regarded as another intermediate, was not identified in any of the extracts from sabellids and serpulids. Both Vevers \& Millott (1957) in Marthasterias glacialis, and Gilchrist \& Green (1960) in Artemia salina have found ketocarotenoids with absorption maxima at $460 \mathrm{~m} \mu$ in light petroleum. 
The carotenoids are quantitatively the most variable of the crown pigments and while initially derived from the food, the worms are clearly selective. Large quantities of astaxanthin would not be expected to be present in the food which is, on the contrary, probably rich in xanthophylls, yet these are poorly represented not only in the crown but also in other parts of the body. The feeding habits of these worms are similar, and while regional differences might be expected, both the constancy of the individual carotenoids present and of their relative abundance at different seasons suggests that these are species characteristics, not direct reflexions of the food. There seems to be no rapid turnover of carotenoid in the crown. Both Sabella spallanzanii and $S$. pavonina fed for a period of 6 weeks on unialgal cultures of known carotenoid content (Isochrysis galbana Parke, Dicrateria inornata Parke, and Dunaliella tertiolecta Butcher) none of which contain astaxanthin, showed no qualitative difference from normal worms.

The pigment most weakly adsorbed on alumina showing an absorption spectrum identical with that of $\alpha$-carotene could be an isomer resembling pseudo- $\alpha$-carotene (Gillam \& El Ridi, 1936) or neo- $\beta$-carotene B (Polgar \& Zechmeister, I942) derived from $\beta$-carotene during preliminary treatment.

The carotenoids are diffuse and apparently dissolved in oil. The other colours to which the pattern is due are present in granular form. The solubility of these orange, claret and purple pigments in acid, their absorption spectra, redox and other behaviour suggest that they are ommochromes. Dr Bernt Linzen has kindly analysed some of the extracts from Eudistylia polymorpha (claret crowns), E. vancouveri, Schizobranchia insignis (claret crowns) and Sabella spallanzanii. His results are as follows.

The pigments of the first three species all behaved as ommins rather than ommatins giving streaks up to $R_{F} 0.7$ with collidine/lutidine/water I : I :2 ascending paper chromatographic system. The $S$. spallanzanii pigment remained at the start as a yellow spot which could be reduced to a red colour with dithionite. The pigments were purified by neutralization of the acid extracts and dissolving the precipitate in alkaline buffer with subsequent precipitation with acid several times. The final precipitate was washed with dilute $\mathrm{HCl}$ in acetone and dried. The following maxima were obtained:

\begin{tabular}{|c|c|c|c|c|c|}
\hline \multirow[b]{2}{*}{ Eudistylia polymorpha } & \multicolumn{2}{|c|}{$5 \mathrm{~N}-\mathrm{HCl}$} & \multicolumn{3}{|c|}{$m / 15$ phosphate buffer $(\mathrm{pH} 7.5$} \\
\hline & 440 & 520 & 210 & & 512 \\
\hline E. vancouveri & 455 & 510 & 216 & & 495 \\
\hline Schizobranchia insignis & 44 & 515 & & & $5 \mathrm{IO}$ \\
\hline Sabella spallanzanii & 465 & & 225 & $(365)$ & $430-35$ \\
\hline
\end{tabular}

The spectra of the Eudistylia and Schizobranchia pigments are those of ommins, that of Sabella spallanzanii is more like that of xanthommatin. The spectra of these purified pigments may be compared with those of the crude extracts given in Table $\mathrm{I}$. 
TABLE 1. ABSORPTION MAXIMA OF THE ACETONE-INSOLUBLE PIGMENTS

\begin{tabular}{|c|c|c|c|c|c|c|c|c|c|c|c|}
\hline \multirow{4}{*}{$\begin{array}{l}\text { SABELLIDAE } \\
\text { Myxicola infundibulum } \\
\text { Sabella spallanzanii } \\
\text { Sabella pavonina } \\
\text { Branchiomma vesiculosum }\end{array}$} & \multirow{3}{*}{$\begin{array}{c}\begin{array}{c}\text { Distilled } \\
\text { water }\end{array} \\
- \\
-\end{array}$} & \multicolumn{3}{|c|}{$5 \mathrm{~N}-\mathrm{HCl}$} & \multicolumn{3}{|c|}{ I \% $\mathrm{HCl}$ :methanol } & \multicolumn{4}{|c|}{ 2-chloro-ethanol } \\
\hline & & 265 & 320 & & - & - & - & \multicolumn{4}{|c|}{ Featureless } \\
\hline & & 255 & - & 455 & - & - & - & \multicolumn{4}{|c|}{ Featureless } \\
\hline & $\underline{435}$ & $\begin{array}{l}260 \\
260\end{array}$ & 二 & $\begin{array}{l}455 \\
460\end{array}$ & $\overline{-}$ & & & \multicolumn{4}{|c|}{ - } \\
\hline \multicolumn{12}{|l|}{$\begin{array}{l}\text { Schizobranchia insignis } \\
\text { Orange }\end{array}$} \\
\hline $\begin{array}{l}\text { Orange } \\
\text { Claret }\end{array}$ & 二 & 265 & 二 & $\underline{465}$ & $\begin{array}{l}265 \\
260\end{array}$ & $\begin{array}{l}390 \\
390\end{array}$ & $\begin{array}{l}455 \\
520\end{array}$ & \multicolumn{4}{|c|}{ 二 } \\
\hline Grey & 二 & 二 & - & - & 290 & & 450 & \multicolumn{4}{|c|}{ - } \\
\hline Eudistylia polymorpha & & & & & & & & \multirow{2}{*}{\multicolumn{4}{|c|}{$\overline{-}$}} \\
\hline $\begin{array}{l}\text { Orange } \\
\text { Claret }\end{array}$ & 二 & $\begin{array}{l}270 \\
267\end{array}$ & 二 & $\begin{array}{l}445 \\
515\end{array}$ & $\bar{z}$ & $\bar{z}$ & 二 & & & & \\
\hline Eudistylia vancouveri & & & & & & & & \multirow{2}{*}{\multicolumn{4}{|c|}{ - }} \\
\hline Green & - & 265 & 325 & 675 & - & - & - & & & & \\
\hline Claret & - & 262 & - & 505 & - & 390 & 505 & \multicolumn{4}{|c|}{-} \\
\hline $\begin{array}{l}\text { Pseudopotamilla occelata } \\
\text { Orange }\end{array}$ & & & & & & - & - & \multirow{2}{*}{\multicolumn{4}{|c|}{ - }} \\
\hline $\begin{array}{l}\text { Orange } \\
\text { Purple }\end{array}$ & 二 & 262 & 二 & 475 & $\overline{265}$ & $\overline{397}$ & $500-520$ & \multicolumn{3}{|c|}{ - } & \\
\hline Chone infundibuliformis & - & - & - & - & - & - & - & \multicolumn{4}{|c|}{ - } \\
\hline SERPULIDAE & & & & & & & & \multirow{2}{*}{\multicolumn{4}{|c|}{-}} \\
\hline Serpula vermicularis & - & - & - & - & - & - & 二 & & & & \\
\hline $\begin{array}{l}\text { Protula intestinum } \\
\text { Pomatoceros triqueter }\end{array}$ & - & - & - & - & - & - & - & \\
\hline Pink & $500 \quad 535$ & - & - & - & - & - & - & - & - & 505 & 545 \\
\hline Blue & - & - & - & - & - & - & - & (272) & 405 & 505 & 542 \\
\hline Galeolaria caespitosa & - & - & - & - & - & - & - & - & 370 & 505 & 545 \\
\hline
\end{tabular}


The Eudistylia vancouveri and Schizobranchia pigments were then subjected by $\mathrm{Dr}$ Linzen to acid degradation by refluxing overnight with a I : I mixture of $6 \mathrm{~N}-\mathrm{HCl}$ and formic acid, and the reaction mixture, after removal of acids, chromatographed in butanol/acetic acid/water 4:I:I, and collidine/lutidine/water $I: I: 2$ systems. The spot of 3-hydroxy-kynurenin was detected by its characteristic fluorescence and corresponded with authentic 3-hydroxy-kynurenin run at the same time. In the second solvent system a red pigment appeared corresponding to 'Farbstoff IV' of Butenandt \& Neubert (1958), a degradation product of ommins.

There is, therefore, no doubt that these particular pigments are ommins. The general similarity of behaviour of the acid-soluble pigments from other sabellids suggests that they belong to the same class of substance, and that their colours differ partly from their association with other compounds. This is suggested by the progressive difficulty of extraction from the light yellow water-soluble pigment of Sabella pavonina through $5 \mathrm{~N}-\mathrm{HCl}$-soluble pigments, to red pigments dissolving in acid methanol and finally to purple pigments dissolving most readily in alkalis. The alternating orange and purple bars in the filaments of Sabella crowns may perhaps be likened to the different individuals of Eudistylia polymorpha or Schizobranchia in which the whole crown is either orange or claret. The green pigment of Eudistylia vancouveri is different. It will be noticed that while all the sabellids with the exception of Chone possess ommochromes, these pigments were not found in any of the serpulids examined.

While the colour of the crowns of Serpula and Protula is due to carotenoids as already emphasized, the main pigments of the other serpulids Pomatoceros and Galeolaria are quite different from those we have been considering. Their solubilities and absorption spectra do not resemble any class of pigment that has been described. It is interesting that the blue pigment of Pomatoceros has a spectrum similar to that of the grey-blue pigment of Galeolaria, and that in Pomatoceros the pink pigment has virtually identical absorption maxi$\mathrm{ma}$ in the red, but lacks the near ultra-violet peak and is water soluble.

All these pigments in the crowns of sabellids and serpulids may perhaps be serving the same primary purpose of screening the tissues from light. Both sabellids and serpulids display their crowns for feeding and for respiration, and while many do so more at night, crowns are often opened in bright light. Schizobranchia insignis collected from wharves usually have a deeply pigmented crown; those I have seen dredged from some depth are much paler.

The nature of the white markings in the crowns of some sabellids and serpulids requires further study. 


\section{SUMMARY}

The pigments in the crowns of a number of sabellids and serpulids have been examined. The main pigments of sabellid crowns are ommochromes, but these pigments have not been found in serpulids. Both sabellids and serpulids also possess astaxanthin, and in Serpula, Protula and the sabellid Chone infundibuliformis it is to this pigment or an ester that the colour of the crown is due. The main carotenoids have been identified and the presence of a possible intermediate ketocarotenoid in amounts varying from one species to another suggests that the astaxanthin or astaxanthin ester is synthesized by the worms from $\beta$-carotene derived from the food. Pomatoceros has pink and blue pigments, and Galeolaria a similar grey-blue pigment which could not be identified with any known class of pigment. Neither these nor ommochromes have previously been found in annelids.

\section{REFERENCES}

DALES, R. P., I96r. The coelomic and peritoneal cell systems of some sabellid polychaetes. Quart. F. micr. Sci., Vol. I02, pp. 327-46.

Butenand, A. \& Neubert, G., I958. Úber Ommochrome XVII. Zur Konstitution der Ommine. Liebigs Ann. Chem., Bd. 618, pp. 167-73.

Føyn, B. \& GJøEN, I. 1954. Studies on the serpulid Pomatoceros triqueter L. Nytt Mag. Zool., Vol. 2, pp. 85-90

Gilchrist, B. M. \& Green, J., 1960. The pigments of Artemia. Proc. roy. Soc. B, Vol. I52, pp. II $8-36$.

GILlam, A. E. \& El RIDI, M. S., 1936. The isomerization of carotenes by electrographic adsorption. I. Pseudo- $\alpha$-carotene. Biochem. F., Vol. 30, pp. 1735-42.

NicolA, M. DE, I954. The carotenoids of the carapace of the echinoderm Ophidiaster ophidianus. Biochem. F., Vol. 56, pp. 555-58.

Polgar, A. \& ZeChMEISTER, L., I942. Isomerization of $\beta$-carotene. Isolation of a stereoisomer with increased adsorption affinity. F. Amer. chem. Soc., Vol. 64, I856-6I.

Vevers, H. G. \& Millott, N., 1957. Carotenoid pigments in the integument of the starfish Marthasterias glacialis (L.). Proc. zool. Soc., Lond., Vol. I29, pp. 75--8c. 